\title{
Islamic View of Women's Rights: \\ An International Lawyer's Perspective
}

\section{Ekaterina Yahyaoui Krivenko *}

What is an Islamic view of women's rights? Is there an authentic Islamic interpretation of this issue? The central argument of this article is that there is no unique Islamic view of women's rights and even more, that according to the very nature and spirit of Islamic law itself, there should be no such version. The article starts with an overview of states' international obligations with regard to protection of women's rights. It continues with some examples of implementation of these obligations in several states proclaiming Islam as official religion and source of legislation. This part of the article demonstrates diversity of views existing among such states and insists on the fact that it is not religion itself, but its misuse by patriarchal totalitarian regimes that impedes any development towards improvement of the situation of women in some Muslim states. Finally, the article suggests that international lawyers shall abandon sacralizing religiously framed defences of certain states and be in contrast more attentive and sensitive to difficulties faced by other Muslim states in their effort to reform and reinterpret Islamic law.

\section{Keywords}

Islam, women's rights, CEDAW, reservations, Saudi Arabia, marriage, divorce, rights and obligations of spouses, custody of children.

* Ekaterina Yahyaoui Krivenko, Ph.D. and D.E.S. (Geneva), LL.M. (Friburg), LL. B. (Belarus and Switzerland) is a postdoctoral research fellow at the Centre for International Studies (CÉRIUM) of the University of Montréal. Her research interests include philosophical, religious and feminist perspectives on such areas of law as human rights, refugee and migration law, comparative constitutional law, Islamic law. The author may be contacted at: ekaterina.yahyaoui@graduateinstitute.ch/Address: 500 Rue François, App. 312 Montréal, QC H3E 1G4 Canada 


\section{Introduction}

In adopting an international lawyer's perspective, one obviously places oneself at the level of international law and has to look for both women's rights and an Islamic view of them in international law. Traditional doctrine of international law recognizing states as principal subjects and lawmakers of international law, although often questioned now, remains largely valid. ${ }^{1}$ For this reason the present inquiry will start with an analysis of the major international treaty dealing with women's rights, the United Nations Convention on the Elimination of All Forms of Discrimination Against Women (CEDAW). ${ }^{2}$ This international treaty ratified by 185 states $^{3}$ is the main codification of human rights norms in their specific application to women. 4

Where does one look for an Islamic view of these rights at the level of international law? From the perspective of traditional international law, only states can express this view. Although strictly speaking states do not have a religion, many states proclaim

1 For some contemporary debates on the role of states in particular with regard to law-formation, see generally Harlan Grant Cohen, Finding International Law: Rethinking the Doctrine of Sources, 93 IowA L. Rev. 152 (2007); Duncan B. Hollis, Why State Consent Still Matters: Non-State Actors, Treaties, and the Changing Sources of International Law, 23 Berkeley J. InT'L L. 1 (2005); Christiana Ochoa, The Individual and Customary International Law Formation, 48 VA. J. INT'L L. 119 (2007); Detlev F. Vagts, International Relations Looks at Customary International Law: A Traditionalist's Defence, 15 EUR. J. INT'L L. 1031 (2004).

2 Convention on the Elimination of All Forms of Discrimination against Women (CEDAW), opened for signature Dec. 18, 1979, G.A. Res. 34/180, 34 U.N. GAOR, Supp. No. 46, U.N. Doc. A/34/46 (1979), 1249 U.N.T.S. 13 (entered into force on Sept. 3, 1981) [hereinafter CEDAW].

3 This represents the number of states as of February 20, 2009. All other legal materials and references are stated as of this date.

4 This is not the only international instrument addressing human rights of women. Other instruments adopted by the U.N. General Assembly include the Convention on the Nationality of Married Women, G.A. Res. 1040 (XI), 309 U.N.T.S. 65, entered into force Aug. 11, 1958; the Convention on Consent to Marriage, Minimum Age for Marriage and Registration of Marriages, G.A. Res. 1763 (XVII), 521 U.N.T.S. 231, entered into force Dec. 9, 1964; Convention on the Political Rights of Women, G.A. Res. 640 (VII), 193 U.N.T.S. 135, entered into force July 7, 1954. Moreover, other U.N. agencies also adopted women-specific conventions in their respective areas of activity. For some examples, see the International Labour Organization's (ILO) Convention No. 100 concerning Equal Remuneration for Men and Women Workers for Work of Equal Value, adopted by the General Conference of the ILO on June 29, 1951, and entered into force on May 23, 1953; the ILO Convention No. 111 concerning Discrimination in respect of Employment and Occupation, adopted by the General Conference of the ILO on June 25, 1958, and entered into force on June 15, 1960; and the Convention against Discrimination in Education, adopted by the General Conference of the United Nations Educational Scientific and Cultural Organisation on December 14, 1960, entered into force on May 22, 1962. The CEDAW also does not limit itself to simple repetition of what already existed at the time of its adoption as rights granted to women by international law; it expands not only the areas covered, but also the content of rights already granted by previous instruments, for example, areas such as nationality (art. 9), education (art. 10), and social security (art. 11(e)). For more detail, see e.g., Ekaterina Yahyaoui Krivenko, Women, Islam AND International LaW within the Context of the Convention on the Elimination of All Forms of Discrimination Against Women 31-39 (2009). 
Islam as their official religion and ultimate source of legislation. ${ }^{5}$ A significant number of these states became parties to the CEDAW.6 What they claim to be an Islamic view of women's rights appears firstly at the level of their reservations which they enter when becoming parties to the CEDAW.7 Later, when fulfilling their reporting obligations, they clarify and give more details on their Islamic view in periodic reports and also in answering questions of the members of the CEDAW Committee, the treaty-monitoring body of the CEDAW. 8 This latter way of expressing views is particularly important not only because it offers an opportunity to get more information and a deeper understanding of various issues involved, but also because states which claim to be Islamic but did not enter reservations when becoming parties to the CEDAW can also express their Islamic vision of women's rights. The vision which otherwise remains invisible and forgotten thus leaving to the outside observer the impression that an Islamic view of women's rights can be conceived only as an opposition - be it partial (reservation) or total (non-adherence to the treaty) - to provisions of human rights law. However, I will not limit my analysis exclusively to states' vision of what qualifies as Islamic view of women's rights for two reasons. Firstly, it would be too narrow and unrepresentative of Islam as a social phenomenon. Secondly, modern international law recognises the significant role played by NGOs in the international arena at various

5 Usually this proclamation is made in the Constitution of the concerned states. See e.g., the Constitution of Afghanistan art. 2; the Constitution of the People's Republic of Bangladesh art. 2A; the Constitution of the Kingdom of Bahrain art.2; the Constitution of Morocco art. 6; the Constitution of Malaysia art. 3 (1).

6 It is difficult to give an exact number of states parties to the CEDAW which can be regarded as Islamic in the sense that they are pretending or attempting to use Islamic law as the source of their legislation. The role of Islam in legislation is often obscured by many factors. For the purposes of this article we will adopt a specific approach to the selection based on more formalistic criteria which will be explained in detail below. At this point I will emphasize the preference for the term 'Muslim states' instead of 'Islamic states' because no state can proclaim to know what is really Islamic as will become clear later.

7 Among these states 21 maintain substantive reservations relating to their application of Islamic law. The issue of reservations made by Muslim states parties to the CEDAW will be addressed in more detail below. For a full listing of reservations to the CEDAW, see http://treaties.un.org/Pages/ViewDetails.aspx?src=TREATY\&id=326\&chapter= 4\&lang=en (last visited on Apr. 3, 2009).

8 The Committee was established in accordance with art. 17 of the CEDAW and is composed of 23 members. The main objective of the Committee is to consider the progress made in the implementation of the Convention. CEDAW, art. 17, para. 1. For the fulfillment of this function it examines periodic reports submitted by states parties and, along with reporting about its activities to the General Assembly of the UN, makes suggestions and general recommendations. CEDAW, arts. 18, 21. The reporting obligation imposed on states includes submission of an initial report within one year upon entry into force of the CEDAW for the state and every four years thereafter CEDAW, art. 18, para. 1. Two main official documents regulating the work of the Committee are the following: the Rules of procedure of the Committee on the Elimination of Discrimination against Women, U.N. GAOR, 53rd Sess., Supp. No. 38, U.N. Doc. A/56/38/Annex 1 (May 14, 1998); and the Revised Reporting Guidelines. Report of the Committee on the Elimination of Discrimination against Women, 27th Sess., U.N. GAOR, 57th Sess., Supp. No. 38, U.N. Doc. A/57/38, part II, Annex (Oct. 8, 2002). 
stages of law-formation and application. ${ }^{9}$ In the context of the CEDAW, as in the work of the U.N. in general, NGOs play a very active and sometimes influential role. 10 They introduce to the international arena a distinct, new voice of persons, human beings concerned. Although, they cannot claim to represent all facets of various human experiences, the introduction of this distinct voice is still important and can offer useful insights for analysis of human rights issues. For the purposes of the present analysis, reference will be made to NGO reports submitted to the CEDAW Committee in preparation for review of states parties' periodic reports.

This paper begins with the analysis of the CEDAW, its genesis, the content of its provisions, followed by a general historical overview of Muslim states' participation in this Convention. The next part will attempt to describe in some detail the most important characteristics of what might be called an 'Islamic view' of women's rights and preliminarily explain the author's use of this term. Finally, the paper will discuss what this view can suggest to an international lawyer, particularly a feminist international human rights lawyer.

\section{Women's Rights as Human Rights}

\section{A. Historical Development}

There have been a number of important stages in the gradual recognition of women's rights by international human rights law, although one should keep in mind that the struggle of women for the recognition of their rights has a much longer history. Both the UN Charter in paragraph 3 of its Article 1, and the Universal Declaration of Human Rights11 in Article 2, recognized the formal equality between men and women as one of the fundamental principles. At this initial stage the concept of human rights was limited to civil and political rights and the main task of women's rights movements was to struggle for transformation of this formal principle into practice of states. However, the

9 See generally Anna-Karin Lindblom, Non-Governmental Organisations In International Law (2005); IsRaEl De Jesús Butler, UnRaveluing Sovereignty: Human Rights aCtors and the Structure of International LaW (2007).

10 The CEDAW Committee encourages NGO participation in consideration of periodic reports, firstly, at the preparatory stage in order to receive additional information on situation of women in countries under consideration, secondly, during the Committee's sessions and consideration of reports. See rule 44 to 47 of Committee's Rules of Procedure, supra note 8, but also the document specifically addressed to NGOs: Committee on the Elimination of Discrimination Against Women, Information note prepared by the OHCHR for NGO participation, available at http://www2.ohchr.org/english/bodies/cedaw/docs/NGO_Participation_EN.pdf (last visited on Apr. 11, 2009).

11 Universal Declaration of Human Rights, G.A. Res. 217A (III), U.N. Doc. A/810 at 71 (1948). 
realization of equality in political spheres responded only partially and inadequately to women's interests as discrimination in other areas continued. The adoption of the U.N. Covenant on Economic, Social and Cultural Rights (CESCR)12 to a certain extent allowed women to articulate their claims in the so-called 'private' domain. The requirement set in Article 3 of the CESCR according to which states in addition to guaranteeing exercise of rights without any discrimination as required by paragraph 2 of Article 2, also "undertake to ensure the equal right of men and women to the enjoyment of all economic, social and cultural rights" [emphasis added], played important role in this context. However, the CESCR could not respond adequately to specific experiences of women not only because of its weak enforcement provisions, but also having been conceived by men and written from a man's perspective it still left untouched many issues central to women's lives. Moreover, the recognition of some women's needs often had a detrimental effect of reinforcing the traditional division of roles between men and women. 13

Thus, the struggle for recognition of the specific experiences and needs of women and elimination of the traditional division of roles became a focal point of the women's movements. Growing influence of these movements in the international arena resulted in consideration by the UN of the necessity and possibility of adopting a convention dealing specifically with women's rights. The preliminary stage of seeking opinions of governments on the possibility of the adoption of such a convention (prior to the year 1975) 14 took a long time and revealed a religious and ideological divide among states which influenced the wording of the convention. The CEDAW, finally adopted in 197915 is conceived as a comprehensive instrument dealing with all relevant aspects of women's lives and responding to specific needs and experiences of women. The comprehensiveness of the CEDAW is due to its wide scope which encompassed all previously guaranteed women's rights oftentimes reformulating them in a more

12 International Covenant on Economic, Social and Cultural Rights, G.A. Res. 2200A (XXI), 21 U.N. GAOR Supp. No. 16 at 49, U.N. Doc. A/6316 (1966), 993 U.N.T.S. 3 (entered into force on Jan. 3, 1976).

13 See The Universal Declaration of Human Rights, supra note 11, at art. 16, para. 3 (aimed at protecting the family, it states, "[t]he family is the natural and fundamental group unit of society and is entitled to protection by society and the State.”). Without any further clarification, this provision can easily be used by states to reinforce traditional division of roles and the conservative vision of the 'natural' role of women. The same remark can be made with regard to art. 10, para. 2 of the CESCR, which states: "The widest possible protection and assistance should be accorded to the family, which is the natural and fundamental group unit of society, particularly for its establishment and while it is responsible for the care and education of dependent children."

14 After 1975, a year which was proclaimed by the United Nations as the International Women's Year (G.A. Res. 3010 (XXVII) (1972)) and was followed by a decade (1976-1985) for Women: Equality, Development and Peace (GA Res. 3529 (XXX) (1975)) there was a rush toward the adoption of the text of the convention, which should be ready for the International Women's Conference planned for the year 1980.

15 CEDAW was adopted by the General Assembly on Dec. 18, 1979. CEDAW, supra note 2. 
inclusive fashion. Moreover, it covered many new areas previously left outside of the realm of the legal sphere.

\section{What are internationally protected women's rights?}

Without reproducing here the text of the convention, it is important to note some of the most significant features of this instrument which are essential to the understanding of its stance towards the protection of women's rights and important for the understanding of the position adopted towards the CEDAW by reserving and nonreserving Muslim states.

The substantive provisions of the CEDAW are divided into two major parts the first of which can be identified as the general part of the convention (articles 1 to 6), and the other as the special part of it (articles 7 to 16). The general part, in addition to containing a definition of discrimination against women, 16 also enumerates all general measures which states should undertake in order to eliminate all forms of discrimination. These measures are not limited to the traditional legal sphere, but also address such areas as culture, media, and the elimination of stereotypes in education. Article 5 of the CEDAW, which addresses culture, is an important and highly controversial provision. The most problematic part of this article requires states to take all appropriate measures:

[t]o modify the social and cultural patterns of conduct of men and women, with a view to achieving the elimination of prejudices and customary and all other practices which are based on the idea of the inferiority or the superiority of either of the sexes or on stereotyped roles for men and women.

This provision has as an aim the simple elimination of customary practices based on the idea of inferiority or superiority of the sexes. However, many anthropological and sociological studies have demonstrated high complexity of many customs, including religious practices which even if appearing detrimental to women to a western observer, cannot simply be eliminated without causing significant additional prejudices to women. Rather, there is a need for a complex web of re-negotiations and internal reforms which are far from being as simplistic as the provision tends to represent

Art. 1 of the CEDAW contains the following definition: "any distinction, exclusion or restriction made on the basis of sex which has the effect or purpose of impairing or nullifying the recognition, enjoyment or exercise by women, irrespective of their marital status, on a basis of equality of men and women, of human rights and fundamental freedoms in the political, economic, social, cultural, civil or any other field." Two of the most important features of this definition are the following. Firstly, the definition is not limited to rights enumerated in the CEDAW. If the right does not appear in the text of the CEDAW, theoretically, it is possible to claim protection against discrimination on the basis of article 1 alone. Secondly, the interdiction of discrimination is not limited to the public sphere, but also extends to the area of private life. For more detail, see e.g., KRIVENKo, supra note 4, at 26-28. 
them. 17

The special part of the CEDAW enumerates rights to be granted and measures to be taken in various specific areas, such as public and political life, education, employment, health and social services, legal and judicial spheres, and most importantly, private and family life. Since it is this latter provision which, as will become clear later, appears to be the most problematic for Muslim states, it will be discussed in more detail.18

Article 16 first requires states to "take all appropriate measures to eliminate discrimination against women in all matters relating to marriage and family relations." [emphasis added]. The list which follows indicates particular areas in which the same rights shall be ensured on the basis of equality of men and women [Emphasis added]. These areas are only examples and the fact that some other areas are not mentioned in the article does not mean that they are not protected by the CEDAW, at least as far as the granting of rights on the basis of equality is concerned. Theoretically, it should be

17 Diane Bell, Considering Gender: Are Human Rights for Women Too? An Australian Case, Human Rights FoR WomEN Too? An Australian Case, Human Rights in Cross-Cultural Perspectives: A Quest for Consensus 339 (Abdullahi A. AN-Na'Im \& ABDUlLAHI eds., 1992) (using as an example the case of Australian aboriginal population); Anne Griffiths, Gendering Culture: Towards a Plural Perspective on Kwena Women's Rights, Culture And Rights: Anthropological Perspectives 102 (Jane K. Cowan, Marie-Benedicte Dembour \& Richard A. Wilson eds., 2001) (addresses traditional practices of polygamy and customary marriage in Botswana). From the point of view of feminist legal theories, this aspect of critiques of CEDAW is closely linked to the so-called Third-world feminist theories which criticise essentialization of a white western educated middle-class woman without taking into account specific experiences of women living in different conditions. See Cheryl Johnson-Odim, Common Themes, Different Contexts, Third World Women and the Politics of Feminism 314 (Chandra Talpade Mohanty, Ann Russo \& LOURDES ToRRES eds., 1991).

18 Art. 16 reads as follows:

1. States Parties shall take all appropriate measures to eliminate discrimination against women in all matters relating to marriage and family relations and in particular shall ensure, on a basis of equality of men and women:

(a) The same right to enter into marriage;

(b) The same right freely to choose a spouse and to enter into marriage only with their free and full consent;

(c) The same rights and responsibilities during marriage and at its dissolution;

(d) The same rights and responsibilities as parents, irrespective of their marital status, in matters relating to their children; in all cases the interests of the children shall be paramount;

(e) The same rights to decide freely and responsibly on the number and spacing of their children and to have access to the information, education and means to enable them to exercise these rights;

(f) The same rights and responsibilities with regard to guardianship, wardship, trusteeship and adoption of children, or similar institutions where these concepts exist in national legislation; in all cases the interests of the children shall be paramount;

(g) The same personal rights as husband and wife, including the right to choose a family name, a profession and an occupation;

(h) The same rights for both spouses in respect of the ownership, acquisition, management, administration, enjoyment and disposition of property, whether free of charge or for a valuable consideration.

2. The betrothal and the marriage of a child shall have no legal effect, and all necessary action, including legislation, shall be taken to specify a minimum age for marriage and to make the registration of marriages in an official registry compulsory. 
more difficult to argue that some special protective measures are imposed on states on the basis of Article 16 due to the employment of the 'same rights' language. However, the Committee was very creative in addressing the issue of violence against women also under Article 16. The argument used by the Committee states that domestic or family violence significantly impairs a woman's "ability to participate in family life and public life on a basis of equality." 19

The use of 'appropriate measures' language in this and many other articles of the CEDAW has significant implications. This indicates that the article does not require from states in order to achieve compliance with the article any immediate result, rather, the compliance is achieved through gradual implementation of various policies having as the final aim equality in the area. This, in turn, does not mean that states can simply remain passive, but that the wording of this provision is clear in indicating that the obligations imposed on states are rather of a procedural nature and indicate direction to be taken in adopting various measures in this area. 20

Despite all possible criticism, the importance of Article 16, as one of the rare attempts made at the level of international law to regulate the so-called private sphere, cannot be overemphasized. As rightly pointed out by the CEDAW Committee on various occasions, the main problem with respect to the enjoyment by women of their rights relates to the fact that even in countries where the principle of equality and nondiscrimination between men and women is proclaimed - often also as a constitutional principle 21 - the realty of women's lives remains subject to discriminatory cultural, customary or religious practices. 22 Such practices are often confined to the private sphere of family life which traditionally did not attract any or only very limited attention of the legislator. Thus, the importance of this article is also in the requirement for the government to intervene, to act where previously it could just remain passive. The private sphere remained for a long time out of the reach of the legislators in many

19 Committee on the Elimination of Discrimination against Women, General Recommendation No. 19, adopted 11th Sess., art. 14, para. 23, U.N. Doc. A/47/38 (1992). All general recommendations of the CEDAW Committee are available at http://www2.ohchr.org/english/bodies/cedaw/comments.htm (last visited on Apr. 2, 2009).

20 For more on this issue and its relationship to reservations entered by Muslim states, see KRIVENKo, supra note 4, at 175-177.

21 This is also the case in many Muslim states including those which proclaim Islam as official religion and source of legislation. See the Constitution of Afghanistan art. 22 (Any kind of discrimination and distinction between citizens of Afghanistan shall be forbidden. The citizens of Afghanistan, man and woman, have equal rights and duties before the law); the Constitution of the People's Republic of Bangladesh arts. 27, 28 (2); the Constitution of Morocco arts. 5, 8; the Constitution of the Islamic Republic of Pakistan art. 25 (2).

22 See the Committee on the Elimination of Discrimination against Women, General Recommendation No 21, U.N. Doc. A/49/38, para. 12 (1994) ("Even where de jure equality exists, all societies assign different roles, which are regarded as inferior, to women. In this way, principles of justice and equality contained in particular in article 16 and also in articles 2, 5 and 24 of the Convention are being violated"). 
Western states. Thus, feminists argued that the situation of women can be improved through the inclusion of the private sphere into the realm of legal regulation. 23 However, paradoxically, the situation in Muslim countries reverses this picture. In contrast to many Western states, the private sphere always remained among one of the preoccupations of Muslim states pretending to apply Islamic law. ${ }^{24}$ This was not, however, necessarily beneficial to women, as will be shown later.

Women's status in their families also influences their ability to exercise their rights in other areas, particularly in civil matters as is visible from the limits imposed in several states on the freedom of movement of women. It is appropriate to recall a number of reservations entered by Muslim states to the fourth paragraph of Article 15. According to this provision, parties shall accord to men and women the same rights with regard to the law relating to the movement of persons and the freedom to choose their residence and domicile. This provision also gave rise to much discussion at the stage of preparatory work, in particular as far as the situation in some Muslim States was concerned. 25 It is interesting to note that article 6 of the Declaration on the Elimination of

23 As far as human rights law is concerned, see Karen Engle, After the Collapse of the Public/Private Distinction: Strategizing Women's Rights, Reconceiving Reality: Women and International LaW, Studies in Transnational Legal Policy No. 25, The American Society Of International Law 143 (DorINDA G. DaLlmeYER ed., 1993); Frances E. Olsen, International Law: Feminist Critiques of the Public/Private Distinction, in Reconceiving Reality: Women and International Law. Studies in Transnational Legal Policy No. 25, The American Society of International Law 157 (Dorinda G. Dallmeyer ed., 1993); Celina Romany, Women as Aliens: A Feminist Critique of the Public/Private Distinction in International Human Rights Law, 6 HaRv. Hum. RTS. J. 87 (1993); Donna Sullivan, The Public/Private Distinction in International Human Rights Law, Women's Rights, Human Rights: International Feminist Perspectives 126 (Julia Peters \& Andrea Wolper eds., 1995).

24 It is interesting to note that the government of Saudi Arabia also refers to philosophical origins of the public/private distinction in Western culture in order to emphasize the absence of this distinction in Islamic tradition:

With Locke, modern liberalism adopted this division, making a distinction between the two whereby the public (the political domain) has a contractual character based on the practice of individual freedom, while the private (the family) is based on natural relations whereby the strongest (here, the man) dominates and subjugates the weaker (the woman) who remains confined to the private sphere. This has had subsequent implications in the form of the antithetical attitudes of women's movements, calling for the dissolution of the family, protection of women from subjugation and the advancement of women toward the public domain to occupy the position previously monopolized by men. In Islam, a woman is not, in principle, confined to the private domain. Like a man, she moves in both domains together, in accordance with the requirements of her own, her family's or society's interests. Furthermore, the values governing the public domain are those which govern the private. Thus justice, counsel and the reciprocal fulfilment of rights are ordained in both domains, and men and women together have responsibility in respect of both. Committee on the Elimination of Discrimination against Women, Consideration of reports submitted by States Parties under article 18 of the Convention on the Elimination of All Forms of Discrimination Against Women: Combined initial and second periodic reports of States Parties: Saudi Arabia, 13, U.N. Doc. CEDAW/C/SAU/2 (Mar. 29, 2007) [hereinafter Periodic Report of Saudi Arabia] available at http://www.unhchr.ch/tbs/doc.nsf/0/ 6812178168439c35c125730e002a9ffa/\$FILE/N0729667.doc (last visited on Apr. 27, 2009).

25 See e.g., the position adopted by Egypt during the 650th meeting of the 26th session of the Commission on the Status of Women, para. 2, at 2, U.N. Doc. E/CN.6/SR.650 (Sept. 27, 1976) See also comments made in this relation by Indonesia (para. 3, at 2) and Iran (para. 5, at 2). 
Discrimination against Women,26 in dealing with similar civil matters, states that equal rights of women in all civil matters shall be ensured by States "without prejudice to the safeguarding of the unity and harmony of the family, which remains the basic unit of any society..." This clause permitting States to justify some discriminatory practices was not included in the text of the CEDAW.

During the negotiations, the position of Muslim States as a group with regard to various provisions of Article 16 was not very coherent or unanimous. 27 The only exception represents reference to unmarried mothers or parents present in some provisional versions of Article 16. Due to the sensitivity of the issue and taking into consideration the fact that relevant provisions might be considered as relating more to the discrimination against children than discrimination against women, provisions containing such references were either deleted or reformulated. 28

Feminist lawyers started criticizing the CEDAW very early, but with the passing of time, weaknesses and omissions of this treaty become even more visible. Issues such as violence against women, the situation of rural women, provisions on the trafficking of women or the attempt at regulating culture are just a few examples. ${ }^{29}$ Nevertheless, the CEDAW remains the major document reflecting a large consensus achieved among states on the content of international women's human rights. However, many questions and doubts about the nature and extent of this consensus were voiced in the doctrine in that a significant number of reservations accompanied accession of many states to the CEDAW. States claiming to apply Islamic law in their national legislations to issues of personal status are often characterized as undermining this largely achieved consensus. 30

26 Adopted by the U.N. General Assembly resolution 2263 (XXII) (Nov. 7, 1967).

27 Thus, while Egypt and Morocco had significant reservations on the sub-paragraph dealing with rights and responsibilities of spouses during and after dissolution of marriage, Bahrain was more concerned with the provision concerning same rights and responsibilities towards children, irrespective of marital status. Compare U.N. Doc. E/CN.6/SR.650, paras. 72-75, 77, 83, 90-92; U.N. Doc. A/C.3/34/SR.70, para. 11; U.N. Doc. A/C.3/33/L.47/Add.2, paras. 204-206; U.N. Doc. A/32/218, para. 127.

28 See reformulation of the introductory paragraph of art. 16 (U.N. Doc. A/C.3/33/WG.1/CRP.1/Add.2, at 13 and U.N. Doc. A/C.3/33/L.47/Add.2, paras. 194-196, 199) and discussions leading to non-adoption of third paragraph of Art. 16 dealing with children born out of wedlock summarized in LARs AdAm Rehof, Guide to the Travaux Préparatoires of the United Nations Convention on The Elimination of All Forms of Discrimination Against WOMEN 184-186 (1993).

29 For a recent example with references to the earlier literature, see Dianne Otto, Disconcenting 'Masculinities': Reinventing the Gendered Subject(s) of International Human Rights Law, InTERnational Law: Modern Feminist Approaches 105 (Doris Buss \& AMbreEna ManjI eds., 2005).

30 See Michele Brandt \& Jeffrey A. Kaplan, The Tension between Women's Rights and Religious Rights: Reservations to CEDAW by Egypt, Bangladesh and Tunisia, 12 J.L. \& ReL. 105 (1995/1996); Rebecca J. Cook, Reservations to the Convention on the Elimination of All Forms of Discrimination against Women, 30 VA. J. INT'L L. 643 (1990); Anna Jenefsky, Permissibility of Egypt's Reservations to the Convention on the Elimination of all Forms of Discrimination 


\section{B. The Issue of Reservations}

As already mentioned in the introduction, reservations entered by states when becoming parties to a particular international treaty express the disagreement of the reserving state with respect to the reserved provisions. This understanding of reservations is also reflected in the definition adopted in Article 2 (1) (d) of the UN Vienna Convention on the Law of Treaties.31 Therefore, it is important to try to identify some possible areas of concern common to Muslim states. In this regard, one must first agree on the definition of what constitutes a Muslim state. The difficulty relates to the fact that many states with a Muslim majority population have purely secular legislation, as many former republics of the Soviet Union. On the other hand, some states with Muslim minorities maintain for them separate legal systems in matters relating to family law in order to preserve application to Muslims of their religious laws, as for example in India or Israel.

For the sake of convenience, it is suggested that that the fifty-seven states members of the Organization of the Islamic Conference (OIC) can be qualified as Muslim for two reasons. Firstly, these states are supposed to have a Muslim majority population. ${ }^{32}$ Secondly, by being members of the OIC, they support the organization's objectives "to disseminate, promote and preserve the Islamic teachings and values based on moderation and tolerance, promote Islamic culture and safeguard Islamic heritage" and "to protect and defend the true image of Islam." 33 Moreover, they undertake that in realizing objectives of the organization "they shall be guided and inspired by the noble Islamic teachings and values." 34 Not all of these states declare Islam to be the official state religion. They also incorporate or claim to incorporate Islamic law in their national legislation to a very different extent. Some states, for example, the previously mentioned former republics of the Soviet Union, have a purely secular legislation, although some traditional or customary practices subsist and discussion on introduction of legislative modifications based on Islamic law can arise. Out of these fifty-seven states only four

against Women, 15 MD. J. INT'L. L \& TRADE 199 (1991); and more recently: Hanna-Beate Schöpp-Schilling, Reservations to the Convention on the Elimination of All Forms of Discrimination Against Women, 3 Reservations to Human Rights Treaties and the Vienna Convention Regime: Conflic, Harmony Or Reconsiliation 30-39 (Inata Ziemele ed., 2004). For a very detailed and nuanced analysis of Muslim states' reservations, see KRIVENKo, supa note 4.

311155 U.N.T.S. 331 (1969) ("'reservation' means a unilateral statement, however phrased or named, made by a State, when signing, ratifying, accepting, approving or acceding to a treaty, whereby it purports to exclude or to modify the legal effect of certain provisions of the treaty in their application to that State").

32 See the Charter of the Organization of the Islamic Conference (OIC) art. 3(2), March 14, 2008 (requiring that the state have a majority Muslim population), available at http://www.oic-oci.org/is11/english/Charter-en.pdf (last visited on Feb. 20, 2009).

33 Id. at art. 1, paras. 11, 12.

34 Id. at art. 2 . 
did not become parties to the CEDAW: Iran, Qatar, Somalia, and Sudan. The Palestinian state is also mentioned among members of the OIC, but having a particular status in international law, it cannot be taken into account for the purposes of participation in the CEDAW. Out of the remaining fifty-two states, twenty-two accompanied their adherence to the CEDAW by substantive reservations intended to protect Islamic law apparently contradictory to some of the CEDAW's provisions. Six of them subsequently modified or partly withdraw their reservations. Turkey withdrew its reservation in total, so that there are twenty-one Muslim states maintaining reservations to the CEDAW.

Despite some common trends, which can be identified in the pattern of reservations entered by Muslim states, two other trends trouble this pattern. Firstly, there are still significant differences between reserving Muslim states and non-reserving Muslim states on the one hand and between reserving Muslim states on the other. Secondly, the same pattern of reservations comparable to that of Muslim states is visible among other states reserving provisions of the CEDAW in order to preserve their culture or religion.

Among Muslim states which entered reservations to the CEDAW there are several which entered, at least initially, general reservations claiming their right to maintain application of Islamic law despite any possible conflicts with the CEDAW. Such general reservations do not allow any insight into the real extent to which the provisions of the CEDAW are affected. However, many of these general reservations were subsequently replaced by more specific reservations indicating provisions of the CEDAW which could be affected as well as, sometimes, the extent to what these provisions are affected. At any case, the consideration of periodic reports of states allows in the overwhelming majority of cases to identify quite precisely possible areas of conflict. Therefore, it can be stated that the most frequently reserved provisions include: parts of Article 2; Article 9, paragraph 2; Article 15, paragraph 4; and various paragraphs of Article 16. However, while some states reserve Articles 2 and 16 as a whole, others specify particular paragraphs affected. 35 These paragraphs are not identical from one state to another. For example, in relation to Article 16, Bangladesh maintains only its reservation to Article 16, paragraph 1 (c), Kuwait chose to reserve paragraph 1 (f), and Malaysia paragraph 1 (a) and paragraph 2 of this article. 36

35 For example, see the reservations of Algeria, Bahrain, and Egypt. It should be mentioned that just because a state reserves, for example, art. 16 in general, it does not mean that all rights enumerated in this article are necessarily affected by the reservation. Analysis of periodic reports submitted, of national legislation of reserving states, and sometimes even just the text of the reservation itself makes it clear, that only some rights are reserved. Thus, the text of the Egypt's reservation explaining the motivation behind it, makes clear that it is basically concerned with rights and obligation of spouses during marriage and upon its dissolution, including the procedure for the dissolution of marriage itself.

36 For a detailed presentation and analysis of reservations entered by Muslim states, see KRIVENKo, supra note 4, at 
It is interesting to observe that this very general trend of reserving some provisions of Articles 2, 9, 15 and 16, is also visible among other non-Muslim reserving states where some kind of culture or tradition is in play. As with Muslim states, it is difficult to state with precision the exact number of such states, because one has first to define the culture or tradition in question. However, a total of twenty-four states, which initially reserved some provisions of the CEDAW on this basis, can be identified. Six of them subsequently withdrew their reservations in total, and five withdrew in part. Obviously, concrete areas of concern do not overlap completely, but as mentioned before, this is also true for reservations entered by Muslim states. What is more significant, is the apparently more easily achieved re-negotiation and thus withdrawal of reservations. Unfortunately, I did not come across any sociological study which would attempt to analyze this difference.

Thus, already at this stage we have difficulties in identifying a uniform 'Islamic' vision of women's rights.

\section{What is an 'Islamic View'?}

\section{A. On Islamic Law and Its Application in Contemporary Muslim Societies}

Before addressing more closely the possibility and ways of defining an 'Islamic View' of women's rights some introductory remarks on the nature of Islamic law are necessary. First of all, it is axiomatic to state that Islamic law is a religion-based law. It derives in the first place from the Quran as God's word revealed to men. Usually, it is also stated that Sunna, or the example of the prophet Mohammad, is the second source of Islamic law. However, neither the Sunna nor the text of the Quran can be compared to a codified law containing rules ready for application. Rather, the traditional Islamic legal theory regards both sources, the Quran and Sunna, as containing a number of indicators which open a possibility for a qualified jurist to develop legal rules applicable to concrete cases. This development or formulation of rules occurs in relation to a concrete case and according to some established methodological principles. ${ }^{37}$ Formation

$115-130$.

37 It was noted twice that the formulation of rules occurs in relation to concrete cases because it indicates both a specificity of Islamic legal system and the particular role of jurists-interpreters. For a better understanding of this aspect of Islamic legal system in the classical period, it is also important to mention the distinct functions exercised by these jurists-interpreters (muftis) and judges (qadis). The former developed legal rules applicable in concrete cases using established methodological principles. Taking the situation as described to them by persons seeking advice, 
and articulation of these methodological principles occurred gradually throughout the history of Islamic legal thought. These principles include, for example, analogical reasoning (qiyas), consideration of consensus (ijma'), and equity (istihsan).38 Thus, the very fact that one or another statement is formulated as a rule of law implies involvement of human reason which cannot claim divinely protected infallibility.

One of the fundamental beliefs of Muslims to be recalled in this context is the belief that only God knows what is the correct, good way of life - or to put in another way, what corresponds to his will. Human beings can only attempt to understand his will, attempt to approach it as close as possible. This attempt is encouraged and rewarded and even conceptualized as an obligation of every Muslim according to his personal abilities, but the attainment of the ultimate and final truth, or better to say the knowledge of this attainment is considered impossible. 39

Thus, Islamic law is rather a methodology developed by jurists for deduction of concrete legal rules from abstract texts which necessarily implies human involvement. Being a methodology, Islamic law is hardly suited for codification and cannot function adequately in the framework of modern nation-states. Personal status codes claiming to be 'Islamic' appear in this connection as anachronisms. 40

\section{B. Status of Women under Islamic law}

If one undertakes an in-depth study of various views expressed in the name of Islam on the issue of the status of women, one is struck by a significant diversity of views. The most obvious example relates to the issue of polygamy. Whereas some authors will not only state that Islam authorizes polygamy limiting it to four wives, but also add that it cannot be forbidden because it is something permitted by God; others interpreting the

they gave answers (formulated rules applicable to the situation described) according to the best of their knowledge of sources and methodology. The latter were concerned with verifying the veracity of the facts advanced by parties to a dispute. For more detail on this distinction, see Muhammad Khalid Masud, Brinkley Messick \& David S. Powers, Muftis, Fatwas, and Islamic Legal Interpretation, Islamic Legal Interpretation: Muftis and Their Fatwas 3 (Muhammad Khalid Masud, Brinkley Messick \& David S. Powers eds., 1996).

38 For a detailed overview of the development of sources of Islamic law from a historical perspective, see WAEL B. Hallaq, A History of Islamic Legal Theories 36-124 (1997). For a shorter version, see Wael B. Hallaq, The ORIGINS AND Evolution of ISLAMic LAW 128-147 (2005).

39 This aspect of Islamic legal theory can be well illustrated by the principle of 'every mujtahid is correct' which means that every person authorised to exercise legal reasoning gives potentially correct advice, as well as by the following saying attributed to the founder of the Hanafi schools: "I know that my opinion is right, but possibly wrong, and that your opinion is wrong, but possibly right." For a more detailed discussion of this issue, see KHALED ABOU EL Fadl, Speaking in God's Name: Islamic LaW, Authority and Women 9-10, 33-39 (2001); and Khaled Abou El Fadl, Conference of the Books: The Search For Beauty in Islam 350-351 (2001).

40 Ann Elizabeth Mayer, The Shari'ah: A Methodology or a Body of Substantive Rules? IsLAMIC LAW AND JURISPRUDENCE 177 (Nicholas HeER ed., 1987). 
same text from the Quran arrive at the conclusion that in order to fully implement the divine will, Islamic societies should prohibit polygamy.41

In order to illustrate this diversity of views even at a purely formal state level, we shall discuss several subjects of personal status and family law, comparing the position adopted on these issues in Saudi Arabia with some other more progressive views expressed by states also qualifying themselves as 'Islamic.' Saudi Arabia was selected for two primary reasons. Firstly, the ruling elite of this country often claims to represent the only authentic Islam. Secondly, the situation arising out of this claim, when reflected through the analysis of some basic premises of classical Islamic legal theory and compared to the situation in other Muslim states, is helpful in illustrating the arguments and conclusions below.

It should be emphasized at the outset that the periodic report submitted by Saudi Arabia to the CEDAW Committee contains just a few general statements without clarifying all detailed issues analyzed below. 42 However, it is quite easy to access more detailed information, firstly, through the Shadow Report prepared for the CEDAW by an NGO called Saudi Women for Reform, 43 and secondly, and most importantly, from many publications distributed by the Permanent Council on Islamic Research and Fatwa. This institution has been established by a royal decree with a specific aim to advise both the ruling elite as well as ordinary individuals on various religious-legal issues. These publications are often construed as a list of questions and answers.44 Their validity derives from the authority enjoyed by lawyers giving answers who are appointed also by a royal decree. 45

The modern interpretations developed by contemporary Muslim scholars on a

41 For the former view, see Yusuf Al-Qaradawi, The Lawful and the Prohibited In Islam 190-193 (1985); for the latter opinion, see the Committee on the Elimination of Discrimination against Women, Consideration of reports submitted by States Parties under article 18 of the CEDAW: Initial report of States Parties: Syria, 88, CEDAW/C/SYR/1 (Aug. 29, 2005), available at http://www.unhchr.ch/tbs/doc.nsf/(Symbol)/d92d2c33f8a25088c1257226003d21e1? Opendocument (last visited on Apr. 28, 2009).

42 Periodic Report of Saudi Arabia, supra note 24.

43 Saudi Women for Reform, The Shadow Report for Cedaw: Saudi Report (2007) [hereinafter Shadow Report], available at http://www2.ohchr.org/english/bodies/cedaw/docs/ngos/womenreform40.pdf last visited on Apr. 28, 2009).

44 For a widely accessible English version of these opinions as well as background of the work of this institution, see their official web-site, available at http://www.fatwa-online.com (last visited on Feb. 20, 2009).

45 The situation in Saudi Arabia is in so far peculiar as not only the personal status and family law remains uncodified, but judicial decisions cannot always be taken as a source for determining applicable laws because they do not have the value of precedents as is the case in common law systems. The best source would probably be widely published collections of opinions of leading jurists. These opinions often constitute a basis for judicial decisions. For more detail on this aspect, see Frank E. Vogel, The Complimentarity of Ifta and Qada: Three Saudi Fatwas on Divorce, in Islamic Legal Interpretation: Muftis and Their Fatwas 262 (Muhammad Khalid Masud, Brinkley Messik \& David S. PowERs eds., 1996). 
variety of issues relating to women will not be addressed here, since for an international lawyer the position of states, and thus their national legislation is more important.46 Issues selected for analysis are those which are the most discussed in relation to reservations entered to the CEDAW by Muslim states: the right to marry and choose a spouse, the rights and obligations of spouses during marriage, dissolution of marriage, custody and guardianship of children upon dissolution of marriage.

\section{Right to Marry and Choose a Spouse (Capacity to Conclude a Marriage Contract)}

Theoretically, a woman's consent is required for the validity of a marriage and a woman shall not be compelled to marry. However, the role traditionally played by guardians of women in this context significantly impairs and often even nullifies this requirement. It is already significant that according to the majority of schools, a woman is not able to conclude a marriage contract without a guardian who should be male. Only the Hanafit school permits conclusion of a marriage contract without a guardian, who has however the right to request annulment of the marriage on the grounds of unsuitability of the husband and insufficiency of dower. 47 Usually this role will be assumed by the woman's father. However, his role is not limited to representing his ward. The main objective of this institution is to check and control the woman's choice. 48 The reason for this is that, according to all schools of Islamic law, a woman should only marry a suitable man. Suitability is defined differently by different scholars and can include such considerations as religiosity, character, wealth, kinship and profession.

The absurdity of situations arising out of a very narrow and women-unfriendly interpretation of the role of a guardian and the suitability of the husband is wellillustrated by a case presented in the Shadow Report. 49 In this case, half-brothers who became guardians of their sister after their father's death were able to annul her marriage, which was concluded with her father's consent, had lasted for years and out of which were born two children. The only reason for the annulment of this marriage was the unsuitability of the husband because of the inferiority of his tribe to that of his wife's. Neither the previously given consent of the father, nor the interests of children, not to speak of that of the husband and wife, were taken into account.

\footnotetext{
46 Some examples of modern interpretations by Muslim scholars on all issues addressed below can be found in: KRIVENKO, supra note 4, at 56-71.

47 Muhammad Amin Ibn Umar Ibn Abidin, 4 Radd Al-Muhtar Ala Al-Durr Al-Mukhtar Shah Tanwir Al-Absar 155 (1994); Abd Al-Halim Abou Chouqqa, 5 Encyclopédie De La Femme En Islam 72 (1998).

48 Some scholars openly recognize that the father can impose his choice on his virgin daughter. Id. For a reference to opinions of scholars in Saudi Arabia, see ABou El FADL, SPEAKING IN God's NAME, supra note 39, at 193-194.

49 Shadow Report, supra note 43, at 13.
} 
This situation is in stark contrast to that, for example, of Moroccan women after the adoption of the new Family Code. 50 According to its provisions, the guardianship is not an obligation imposed on women, but a right granted to them (Article 24) which they can exercise or not according to their choice (Article 25). There is also no provision in the Family Code which would authorize the guardian to request the annulment of the marriage just because he does not agree with the choice of his ward. In other countries, where the institution of guardianship for women is maintained, legislators introduce various safeguards against possible abuses. For example, in Malaysia, the Islamic Family Law, Article 7, maintains the requirement of the guardian's consent in order for the marriage to be valid. However, it allows for the possibility to replace the guardian's consent by authorization of a judge "where the wali [guardian] refuses his consent without sufficient reason." 51 Moreover, the Act punishes, including by imprisonment, not only any attempt to prevent or to compel a person to marry (Article 37), but also the making of false declarations in order to compel or prevent a person to marry (Article 38). In addition, the fact that a woman was compelled by one or another means to a marriage is listed in Article 52 (1) as a valid ground for requesting a dissolution of the marriage.

The situation in Saudi Arabia is in a sharp contrast to these attempts. Not only are the powers of the guardian unrestricted, but the abuse is even facilitated by the maintenance of a very archaic rule governing the issue of women's identification in legal proceedings, described in the Shadow Report. 52 Theoretically, the officer performing the marriage will ask woman's consent, but since the woman is supposed to be covered from head to toe and neither this officer nor any judge will look at the woman, she has to be identified by two close male relatives. So they can present any woman and attribute her the identity they need. The woman whose identity and thus consent was misused in this way has no possibility to contest acts undertaken in her name because in order to go to a court or a judge she not only again needs the consent of the two male relatives, but is also identified in the same way. Thus, the abuse of power by guardians is not only unrestricted, but even facilitated by the Saudi Arabian legal system. Moreover, it is obvious that such rules regarding identification and access to courts will constitute impediments to the exercise by women of a panoply of rights, even those expressly granted and recognized by Saudi Arabian law.

\footnotetext{
50 Morocco, Family Code (Moudawana), dahir $\mathrm{N}^{\circ} 1-04-22$ of 12 hija 1424 (Feb. 3, 2004) promulgating law $\mathrm{N}^{\circ} 70-03$ Bulletin Officiel $\mathrm{n}^{\circ} 5358$ du 2 ramadan 1426, 667, available at https://hrea.org/moudawana.html (last visited on Feb. 20, 2009).

51 Islamic Family Law (Federal Territories) Act (1984), art. 13 (b).

52 Shadow Report, supra note 43, at 66-67.
} 


\section{Rights and Obligations of Spouses during Marriage}

The conservative view of rights and obligations of spouses can be summarized as the husband having an obligation to provide for material needs of the family in return for which the wife has to be obedient to her husband in all areas of life. According to this version of the 'Islamic' view of family life, the husband is attributed the status of the head of the household because of his apparently better earning ability and obligation to provide for his wife and children. 53 This material obligation imposed on the husband allows him to require from his wife to forgo her entire independence and autonomy.

In a system like that of Saudi Arabia, a woman needs the approval or authorisation of a close male relative (which for a married woman most often will be her spouse) for a variety of acts: work, going outside, traveling, conducting proceedings before a court, searching admission to educational institutions, entering hospitals for surgery including child birth, or registering the birth of a child. The situation of a married woman is far more restricted due to the duty of obedience to her husband that is imposed on her. This duty is understood very broadly and includes a variety of daily matters, including sexually satisfying her husband. 54 Women are continually reminded by religious scholars of the necessity to be patient and to make every effort to keep their husbands satisfied in order to preserve the unity and stability of the family and the well-being of children. .5 This insistence on and care for the stability of the family and the well-being of children is in so far astonishing as only women are required to strive for this. The legal system, as it operates in Saudi Arabia, does not show any degree of respect for the family and well-being of children, as shown in the case above where a woman's male family members may annul the woman's marriage of several years. Neither do you find this care in consideration of matters of custody and guardianship of children, as will be established below. Similarly, the system for dissolving a marriage maintained in Saudi Arabia demonstrates complete disregard for all these values (care for children and

53 Suleiman Bin Abdul Rahman Al-Hageel, Human Rights in Islam and Their Applications in the Kingdom of Saudi ARABIA 198 (2001) ("[T]he woman has less earning power than the man due to the fact that once she marries, the burdens associated with pregnancy, childbirth and motherhood make it more difficult for her to earn as much as men can, generally speaking”).

54 For a discussion of some issues addressed by Saudi jurists in this relation, see KHALED ABou El FAdL, SPEAKING IN GoD's NAME, supra note 39, at 196-197 (2001). For general references to juristic opinions about obedience even to wrong and unjust husbands, see id. at 210 .

55 It is striking that according to the logic of opinions of many official Saudi jurists it is more important to be obedient to husbands than to God, the pleasure of God being made contingent upon the pleasure of husbands, even unjust and violent. This assertion contradicts the vary nature of Islam which is defined as a religion of submission to God alone. Khaled Abou El Fadl discusses extensively the inner contradictions of such statements and demonstrates their inconsistency even from the point of view of classical Islamic law analysis. Id. at 218-222 and chapter 7 more generally. 
stability of the family) except when it is a woman who wishes to initiate a divorce procedure.

Such regulation of women's status makes a woman completely dependant from her male relative, and particularly from her husband upon her marriage, depriving her from the possibility to exercise effectively her rights in other areas where, theoretically, her rights are not restricted. Thus, for example, Islamic law does not restrict a woman's right to dispose of her property or to initiate a lawsuit, but if she needs two male relatives to identify her for purposes of any act, she will never be able to perform them independently. It should be emphasized that married women are affected more severely than unmarried women. This fact is openly acknowledged, for example, in the reservation to the CEDAW made by Niger. In relation to women's rights to choose their place of residence and domicile, the government states that it can only respect this right with regard to unmarried women:

The Government of the Republic of the Niger declares that it can be bound by the provisions of this paragraph, particularly those concerning the right of women to choose their residence and domicile, only to the extent that these provisions refer only to unmarried women. 56

In other Muslim countries women are rarely restricted in their rights to the degree prevailing in Saudi Arabia. Morocco and Tunisia went so far as to define rights and responsibilities of spouses as reciprocal and mutual and do not feel necessity to legalize wife's duty to obedience, despite the fact that legislation of both countries is claimed to be derived from Islamic sources. 57 Morocco even abolished any reference to the

56 Supra note 7.

57 See paragraphs 1 and 4 of the Preamble to the Moroccan Family Code, supra note 50, for reference to Islam as a source of legislation and importance of ijtihad (independent legal reasoning for finding new solutions to arising issues); See also paragraph 1 of the Law promulgating Personal Status Code of Tunisia: Decree of 13 August 1956 also, available at http://www.jurisitetunisie.com/tunisie/codes/csp/Menu.html (last visited on Apr. 3, 2009) (for reference to Islam). With respect to Morocco, the new Family Code defines rights and obligations of spouses as reciprocal (Compare art. 51 of the Family Code with art. 36, para. 2 of the previously applicable Moroccan Law of Personal Status). Art. 23 of the Tunisian Personal Status Code defines rights and obligations of spouses as mutual and reciprocal, except for the obligation of the husband to support the family. It is also interesting to note that other Muslim communities are receptive and open to such new interpretations. One example is the Counter Legal Draft to the Indonesian Compilation of Islamic Law. This draft was prepared by a group of Islamic legal scholars led by a Special Assistant to the Minister of Religion. In this draft rights and obligations of spouses are defined as equal and no reference is made to the husband as head of the household. Unfortunately, due to critical reactions of some scholars, it did not pass into a law. But the very fact that an egalitarian vision of rights and obligations of spouses is possible in an Islamic context is well confirmed by this draft. For more detail on this document and its history, see Siti Musdah Mulia \& Mark E. Cammack, Toward a Just Marriage Law: Empowering Indonesian Women Through a Counter Legal Draft to the Indonesian Compilation of Islamic Law, ISLAMIC LAW IN CONTEMPORARY INDONESIA 128 (R. Michael FEenER \& MarK E. CAMMaCK eds., 2007). 
husband as head of the household. 58

\section{E. Dissolution of Marriage}

According to all schools of Islamic law, divorce is an original right of the husband. He can divorce his wife by simply pronouncing a specified formula three times. The rationale behind placing the decision in hands of husbands is based firstly, on the previously established obligation of the husband to support his wife and, secondly, on an assumption about the nature of men and women:

The power to initiate divorce was given to the man in Islam because the man is more likely to be concerned to keep the wife whom he has spent his money on ... because the man is more capable of balanced thinking and the sound assessment of the outcomes resulting from divorce. 59

Even if these assumptions are not questioned as such, but rather compared to other assumptions about the nature of men, especially those which are used as justifications for allowing polygamy and imposing on women the requirement of a veil, it is possible to undermine this justification. Thus the same author, when describing the reasons behind allowance of polygamy, states the following:

One of the justifications for polygamy is that there are some men with especially powerful sex drives but whose wives have less sexual desire or whose menstrual period lasts a long time each month. In such a case, the man has only two choices if he wants to release his excessive sexual energy: to take another wife, or to engage in extramarital intercourse, which is forbidden in Islam. 60

Similarly, when justifying the rule on women's veiling he states:

If a woman is obliged to pass though the men's sphere of activity once a day, for example, she can veil her face and go about her business without being in danger of causing temptation. However, if women's faces and the other aspects of their physical beauty remain uncovered, and if men are still commanded to lower their gazes and remain chaste, this becomes unbearable for men ...61

See art. 1 of the previously applicable Moroccan Law of Personal Status (the husband was expressly declared as head of household. There is no comparable reference in the new Family Code).

59 RAHMAN AL-HAGEEL, supra note 53, at 202, 204.

60 See Rahman AL-HageEL, supra note 53, at 206. This explanation is very widespread among Muslims defending permission of polygamy. See also YUSUF AL-QARADAWI, supra note 41, at 192-193.

61 See Rahman AL-Hageel, supra note 53, at 210. 
How can a man, who is simply unable to control his sexual desires if he sees a beautiful woman's face, be able to make a reasonable judgement about dissolution of his marriage if, for example, this beautiful woman agrees to marry him only if he divorces his previous wife? What kind of balanced thinking in matters of divorce can we expect from a man whose life is driven by his sexual desires?

All traditional interpretations of Islamic law also recognize other forms of divorce which can be useful to women if only their effective functioning would be guaranteed. Thus, both husband and wife have the right to request divorce on the ground that they would suffer harm if remaining married. Women in addition have the option to request divorce for material consideration. According to the traditional doctrine of Islamic law, this last form of divorce gives the possibility to women to request a divorce without having to prove any harm suffered if remaining married. Despite these options theoretically open to women to initiate divorce, their position is impaired by inadequate application and enforcement possibilities. Women have difficulties in bringing evidence to court, for example, evidence of physical abuse by their husbands. When attempting divorce for material consideration, women have to face abusive demands of their husbands which can also include merchandising custody of children. Moreover, according to the Shadow Report, judges in Saudi Arabia do not grant divorce for consideration without a woman having demonstrated that she suffers harm if remaining married despite the fact that the very raison d'être of this form of divorce is to allow women to divorce based on their will without requiring proof of any harm. 62

Many Muslim countries despite their reluctance to abandon this traditional vision of the system of dissolution of marriage, being well aware of difficulties and burdens placed on women and the possibility of abuse by men, introduce various measures intended to palliate shortcomings of the system. Thus, many countries while maintaining the unconditional right of the husband to divorce recognize this form of divorce only if effected before a judge, so that the divorced woman can at least be informed about her husband's decision. 63 This also allows a judge to regulate other consequences of divorce, such as maintenance or guardianship and custody of children, taking into account information obtained during various procedures in front of the court. The grounds on which women can request divorce, i.e., for harm suffered, are defined as broadly as possible to include even cases when women are simply unhappy

62

63 See art. 83 of Mauritanian Personal Status Code promulgated by Law No 2001-052, French text available at http://www.carim.org/legaltexts/LE2MAU001_FR.pdf (last visited on July. 19, 2001) (obliges the husband to pronounce the divorce either before a judge or a conciliator and to attempt a reconciliation, which obviously gives this judge or conciliator the opportunity to get an insight into reasons for divorce and treat more appropriately any claims of the divorced women, in particular with regard to maintenance). 
in the marriage.64 The divorce for consideration is subject to the judge's control in order to avoid abusive demands by husbands, such as foregoing of custody rights by the woman. Thus, in Mauritania, the Personal Status Code expressly requires that the object of compensation shall be legal and if there are some irregularities, the divorce remains valid, but the husband receives nothing (Article 92).65 Moreover, if upon such a divorce for compensation a woman can establish that she used this procedure in order to escape mistreatment or prejudice caused to her by her former husband, not only does the divorce remain valid, but the husband is obliged to return what he received (Article 93). Even more far-reaching is the protection accorded to women in Malaysia. The negotiation of the amount of compensation always occurs before a judge who, in case of disagreement about the amount, can determine this amount himself taking into account the status and financial means of the parties.66

\section{F. Custody and Guardianship of Children upon Dissolution of Marriage}

According to the traditional doctrine of the four schools of Islamic law, upon dissolution of a marriage the custody (physical care) of the child is attributed to the mother until the child reaches a certain age. The guardianship (legal representation) always remains with the father, or if he is judged unfit for this role, it is attributed to another male relative of the father's family, but not to the mother. The father or another male relative also acquires the custody of the child after the age limit is reached or if the mother remarries. Interestingly, there is no unanimity and a significant difference among schools with regard to the age-limit after which the mother loses her custody. According to some of the most conservative opinions, a boy will be transferred to the father after the termination of the period of breast-feeding which is fixed at two years; other versions include the age of marriage for girls and age of 15 for boys. The justification for nonattribution of guardianship and only limited custody rights to the mother usually involves some assumptions about the nature of women which arguably prevents them from caring appropriately for the child, especially as far as the earning potential is concerned.

See the Egyptian legislation which, although based on the Hanafi interpretation traditionally recognizing very limited number of grounds as harming, incorporates many other grounds traditionally defined by other schools of Islamic law. Consider also the inclusion among grounds for divorce of a general clause of "any other ground which is recognized as valid for [the] dissolution of marriages" in art. 52 (1) (l) of Islamic Family Law (Federal Territories) Act (1984) in Malaysia.

65 Law No 2001-052 promulgating Personal Status Code, French text available at http://www.carim.org/legaltexts/ LE2MAU001_FR.pdf (last visited on Feb. 20, 2009).

66 See art. 49 (3) of the Islamic Family Law (Federal Territories) Act (1984). 
According to the approach commonly adopted by judges in Saudi Arabia with regard to this issue, custody is given to the mother till the boy turns nine, or till the girl turns seven, unless the mother remarries, in which case she loses her custody. After that date, the custody is automatically transferred to the father.67 As stated in the Shadow Report:

The principle of "who is more fitting" for custody is not a factor in changing this equation. Thus the father is accorded the right over the mother even if he is drunkard or violent. The mother's capacity to custody could be jeopardized by the fact that she does not cover her face or listen to music or has a satellite TV. The matter is subject to the discretion of the judge ... 68

The report emphasizes that even the father's unemployment and the fact that it is the mother who actually earns and supports herself and the child is not considered by judges as a reason for granting custody to women. ${ }^{69}$ This stance is in complete contradiction with the reasons invoked for not granting custody to women (namely, ability to provide financial support to the child) and demonstrates that this discriminatory rule is yet another example of the absurdity of patriarchy.

This system of depriving women from effective relationships with their children upon dissolution of marriage appears even more shocking if one considers legislative solutions adopted in various Muslim countries in order to mitigate negative consequences for women and children and ultimately, establishing best interests of the child as a guiding principle. Let us consider, for example, the solution chosen by the Moroccan legislature. According to Article 171 of the Family Code, the mother has priority in acquiring physical custody of the child upon dissolution of marriage without any regard to the age of the child. This custody can be assumed by the mother until the child reaches majority, whether a boy or a girl, unless the child chooses the father at the age of 15.70 The law also sets limits to the automatic termination of the mother's custody upon her remarriage. The child remains in the mother's custody (even if she remarries) if the child is under the age of seven, if the separation from the mother will be prejudicial to the child, if the child's state of health requires the mother's care, if the person to whom the mother is married is a close relative of the child or his guardian, and finally and most importantly, if the mother is the guardian of the child. According to Moroccan Family Code, although the father is the natural guardian of the child

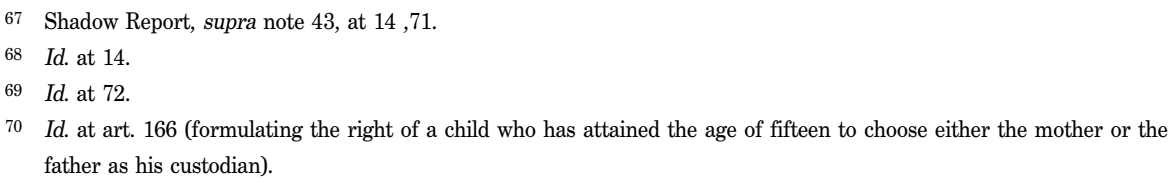


(Article 236), the mother can obtain guardianship (legal representation of the child) in case of father's death, absence, incapacity or as the law adds "for any other motif." 71 Such regulation of the issue of custody and guardianship of children upon dissolution of marriage, although leaving in place certain discriminatory presumptions, significantly diminishes the negative consequences for women and children, but also limits possible interference into the mother-child relationship by other family members.

Before closing discussion on this issue, I would like to make the following additional remark. It is too simplistic to assume that the introduction of the best interests of the child principle will in itself suffice to improve the situation in Saudi Arabia and other countries which have such an anti-progressive approach to women's rights in Islam. This principle can be very helpful in other countries, where prejudices against women are less strong and there exists a certain tradition of women's involvement in society, as for example in Bangladesh and Pakistan. In these countries, despite persistent difficulties faced by women in certain areas, courts are able to overrule some interpretations of Islamic law giving custody of children to the mother on the basis of the best interests of the child.72 In Saudi Arabia, it may be possible to avoid the most flagrant abuses of children using the principle of the best interests of the child, but it does not necessarily mean that women will have more opportunities to acquire custody of their children. The argument will go in the direction of invoking some innate characteristics of women, preventing them from taking care of certain aspects of child's education, and the custody will rather be attributed to the child's close relatives from the father's family, but not necessarily to the mother.

\section{G. Concluding on 'Islamic View'}

The analysis made above has clearly demonstrated that despite all impediments to the correct functioning of Islamic law in the framework of modern nation-states, the diversity of views and interpretative possibilities persists. This diversity is visible not only at the informal level of scholarly discussions, which was intentionally left out of consideration for the purposes of this contribution, but also at the official legislative state level. There are many factors influencing the possibilities of and ways taken by

71 See art. 238 (2) of Moroccan Family Code, supra note 50. It is also important to mention that although the father can choose a guardian to be appointed after his death, the father's choice of guardian is first subject to judiciary control, and the rights of the guardian are limited to supervising the mother's acts and decisions in relation to her child. The guardian thus appointed cannot take any decision regarding the child in place of the mother. In case of doubts or contestations, the intended guardian has to initiate procedure before judge or tribunal.

72 The most well-know decisions include Md. Abu Baker Siddique et al., 38 Dhaka Law Reports (AD) 1986; Mst. Zohra Begum et al., Pakistan Legal Decision 695 (1965). 
these interpretative processes. A majority of these factors has nothing to do with religion, but are rather linked to the nature of the political regime in place. A combination of totalitarianism and patriarchy makes any advancement for women, even an advancement motivated by religious factors simply impossible.

It is also important to emphasize the fundamental possibility and necessity of a diversity of viewpoints within the Islamic legal tradition. Even the few examples of more women-friendly interpretations of Islamic law given above demonstrate the realty of a variety of ways in which the improvement can be achieved. There is no universal solution, no unique 'Islamic' women-friendly interpretation. Each society, each country has to go its own way, taking inspiration from the experience of other nations, but also from its own unique conditions and circumstances.

\section{What to Choose?}

Given these divergent possibilities, all of which are justified in terms of Islamic law, is there one opinion which can be regarded as more authentic than another? How shall international lawyers, who in one way or another have to deal with issues arising around application of Islamic law, approach this diversity of views?

First and foremost, given the precepts and underlying principles of Islam as well as the historical development of Islamic legal culture, it is very troubling that the ruling elite appropriates the right to define religious obligations for ordinary individuals leaving them no room to exercise personal choice.

Islamic legal tradition is very rich in accounts about independence of jurists, authorised to derive concrete legal rules from original sources (e.g., from the Quran and Sunna). Many contemporary scholars have demonstrated that the tradition of dissociation of jurists from political power which was associated with vice was central to the correct functioning of the traditional Islamic legal system. The ultimate source of jurists' authority came from their morality and independence from corrupted power.73 What we observe in many Muslim states today is the opposite of this picture of an independent and morally responsible jurist's figure. By definition, the legislature in modern states is a part of state apparatus and, thus, of the ruling elite. A majority of Muslim jurists are dependant on a state's support and funding.

Furthermore, one of the features of classical Islamic legal discourse is the respect of

73 See Wael B. Hallaq, supra note 38, at 178-226 and WaEl B. Hallaq, "Muslim Rage" and Islamic Law, 54 HastingS INT'L \& Comp. L. Rev. 1705 (2002-2003), at 1708-1709. 
opinions of other scholars including those coming from other schools of Islamic law. From this point of view the situation in Saudi Arabia where only one interpretation is chosen as appropriately Islamic and enforced by authorities on every citizen represents a complete denial of Islamic values.

From a more general point of view, once the legislation becomes a matter of politics and choices are made by the state, as it is the case in all parts of Muslim world since the creation of modern nation-states, this legislation, be it secular or inspired by Islamic values shall necessarily become subject to contestation, negotiation and also critique by all members of a given society. The very fact of the state's influence and involvement in rule-formation and formulation deprives them of any claim of authenticity and infallibility. In contrast, the very fact that rules are negotiated by all members of a Muslim community, in order to reach the best possible solution in accordance with indicators provided by God, allows these rules to make a claim of religious origin or inspiration. In order to keep this characteristic (i.e., rules being derived from religious teaching and retaining some kind of Islamic character) they should always remain subject to contestation and re-negotiation by members of any given Muslim community. Once it is claimed that established rules are the best and the only Islamic way of regulating a particular area, they immediately lose even this minimalist religious character.

What conclusions should international lawyers who regard themselves as outsiders to this negotiative process draw from the above suggestions? First, they should abandon tendency towards the sacralization of laws which claim to be Islamic. This tendency is still often visible in international law and is mainly expressed as the essentialization of one or another interpretation of Islamic law adopted into official legislation as the only and ultimate Islamic law. The interpretation in question will usually be one of the most detrimental to women. Moreover, in doing so international lawyers implicitly deny to Muslim women (rarely to men) the right to freedom of religion, the right to think differently and adopt another version of Islamic law. ${ }^{74}$ In contrast, what international lawyers should not forget, is the difficulty faced by many Muslim states and communities in dealing with such highly valued cultural-religious issues. Muslims expressing views on Islam that are divergent from official interpretations adopted as laws in their countries of origin shall have an opportunity to be heard at least at the international level.

74 A very good example of such an attitude is the treatment of asylum claims made by Muslim women. See generally Susan Mussarat Akram, Orientalism Revisited in Asylum and Refugee Claims, 12 InT'L J. Refuget L. 7 (2000). 